\section{Painless Labour}

Q.-Have any of the leading obstetricians personally confirmed Dr. Grantly Dick Read's methods of ensuring painless childbirth in normal labours as described in his book "Revelation of Childbirth"?

A.-Most obstetricians agree with the principles underlying Dr. Dick Read's methods and believe that the management of the patient as he suggests is conducive to easier and more natural labour. However, there are few if any who would go so far as to agree that the application of such methods, except perhaps in the very occasional susceptible patient, results in the labour being entirely painless.

\section{Gouty Deposits}

Q.-A female patient aged 69 suffers from attacks of gout affecting the great toe and thumb. This is a clinical diagnosis unconfirmed biochemically. From time to time small, hard, red areas appear on the palmar surfaces of the fingers. These gradually soften and when incised yield a substance the colour and consistency of "off-white" paint, which contains polymorph cells but no organisms. What is this condition?

A.-The description suggests that the fluid contains sodium biurate crystals, and if these are found the diagnosis of gout is confirmed. In long-standing cases of gout the sodium biurate is deposited in the cartilages of the joints, along the tendon sheaths, and in the subcutaneous tissues. In the latter situation the deposits are liable to cause local inflammation, which may finally ulcerate through the skin and discharge the "white fluid." A skiagraph of the hand would also settle the diagnosis.

\section{Sterilization with Penicillin}

Q.-Would one or two penicillin lozenges dissolved in a pint bottle of milk help towards its sterilization? Or would the acidity or alkalinity of the milk render it inert?

A.-Unless the milk were already almost unfit for consumption its reaction would not be a serious obstacle. There are two others of more importance. The lesser of these is the dependence of the bactericidal action of penicillin on temperature: the lower this is the less would the effect be. The greater difficulty is the varied flora with which the penicillin would have to contend. We know of no information about the susceptibility to penicillin of the various bacteria concerned in the souring of milk, but it is very likely that some of them would be much more resistant than pathogenic Gram-positive species. If coliform bacilli were present, as they commonly are in unsatisfactory milk, they would not only grow in spite of the presence of penicillin but would destroy it. Penicillin would in no circumstances sterilize milk: it could only reduce the numbers of bacteria or prevent their further growth. In present circumstances it surely remains a duty only to use penicillin for the treatment of disease, and in cases where there is a reasonable expectation of benefit. To degrade such a substance by trying to make it compensate for unhygienic methods of handling milk would be a waste of the worst kind.

\section{Congenital Pyloric Stenosis}

Q.-Please enlighten me on the aetiology (particularly the predisposing factors) of congenital pyloric stenosis.

A.-Congenital pyloric stenosis is undoubtedly inherited, but it is uncertain whether the disorder is recessive or dominant. Studies of large numbers indicate a higher degree of cousin marriages among the parents than would be expected on a chance sample of the population, which favours a recessive gene. On the other hand recorded instances of a child and his parent both having the disorder are not uncommon, and pedigrees have been published which give the appearance of a dominant gene. The condition has been found at birth and even in a foetus, so that the cause must be prenatal and not due to feeding or any postnatal factor. Some disorder of the autonomic system is usually postulated, but it is also said that the so-called hypertrophied muscle is abnormally packed with glycogen, as is found in Von Gierke's disease.

\section{INCOME TAX}

Car Transaction

D. $N$. bought car $A$ while acting as an assistant and in receipt of an (untaxed) car allowance. On being called up to the R.A.M.C. he sold the car, and in November, 1945, bought car B. He resumed the assistantship in January, 1946, and became a partner in the practice in April, 1946.

** No deduction can be claimed for the purchase of the car at a time when he was not professionally engaged. In the circumstances D.N. wili have to confine his claim to the depreciation allowance for $1946-47$.

\section{Income Arising in a Dominion}

"ANTIPODEAN" states: "I am at present living and earning income in this country but my domicile is in New Zealand." He has investments -in a Dominion on which lee pays income tax there; so far no remittances have been made to the United Kingdom. What is his position as regards British income tax?

${ }_{*}^{*}$ In the case of any person who satisfies the Commissioners of Inland Revenue (as presumably "Antipodean" can do if required) that he is not domiciled in the United Kingdom, tax is payable not, as in other cases, on the amount arising abroad, but on the sums which have been or will be received in the United Kingdom. In the circumstances "Antipodean" need not include the income in his British income tax return unless and until some amount is received in this country. As the law now stands he will then be liable to British tax, less the appropria'e Dominion income tax relief, and the amount of the remittance in so far as it is covered by income arising abroad while he is in the United Kingdom.

\section{LETTERS, NOTES, ETC.}

\section{Mites in Sputum}

Dr. Reginald Fisher (King's Langley) writes: Perhaps it may be of interest to record that in 1913 I found mites in the sputum of a case of lung abscess following empyema in a man who had never been out of England. In one specimen I found the detached leg of a mite, in another a complete insect somewhat resembling a cheese mite. Up to now I have thought of these as contaminants.

\section{Medical Service in Australia}

Dr. Ian Gilliland (Hessle) writes: Sir Ernest Graham-Little builds up a strong case in his letter (Aug. 24, p. 272) on information which he received from a colleague in Canberra. This states " that an Act embodying the socialist aspirations for a State Medical Service was passed some years ago by the Socialist Government " of Australia. This statement came as a considerable surprise to many. Sharing this surprise, the editor of the Medical World wrote to the High Commissioner of the Commonwealth of Australia and received the foilowing information: "I have to advise you that no Bill to establish a State Medical Service has been introduced into the Commonwealth Parliament of Australia." In view of this contradiction and of the importance attached to the whole episode by Sir Ernest Graham-Little, I feel that a further explanation is called for.

\section{Children in Nurseries}

“E. D. F" writes: With reference to Mrs. G. M. Woolf's letter D (Aug. 31, p. 318), fifteen years ago I worked in a voluntary day- 을 nursery. There it was customary to use small squares of old linen $\mathrm{N}$ for nasal hygiene, burning the soiled ones immediately. Recently on 0 return to nursery work I was again confronted with the never-ending $N$ problem of nasal catarrh. By regular morning cleaning of each $\sigma$ child's nostrils, and by the use of hard-baked rusks, there was great $<$ improvement. Possibly the exercising of the nasal and oral passages kept the "huns on the run."

\section{The Late Dr. E. H. van Somere}

An obituary notice and appreciation of Dr. E. H. van Someren, O who died at Syracuse, appeared in the Journal of March 15, 1913. Distress has been caused to his family by the wholly erroneous statement in a recent book of memoirs that Dr. van Someren suffered from melancholia and committed suicide.

\section{Correction}

Mr. Harry Freeman writes: My letter in the B.M.J., 1945, 2, 510, states that "the oesophagus is deficient behind in the upper $1 \frac{1}{2}$ in., there being a dehiscence of the inner longitudinal fibres." This : should read the "outer longitudinal fibres," and Dr. C. Ailan Birch very kindly drew my attention to this clerical error on my part. 